\title{
Effect of an Interleukin-1 Receptor Antagonist on the Hemodynamic Manifestations of Group B Streptococcal Sepsis
}

\author{
JULIO D. VALLETTE, JR., RONALD N. GOLDBERG, CLEIDE SUGUIHARA, TERESA DEL \\ MORAL, OCTAVIO MARTINEZ, JING LIN, ROBERT C. THOMPSON, AND \\ EDUARDO BANCALARI
}

Department of Pediatrics, Division of Neonatology Department of Microbiology and Orthopedics, University of Miami School of Medicine, Miami, Florida, and Synergen Inc., Boulder, Colorado [R.C.T]

\section{ABSTRACT}

IL-1 is purported to be a proximal mediator in the cascade leading to septic shock. To characterize its hemodynamic effects and to ascertain whether its blockade would ameliorate the deleterious consequences of sepsis, an IL-1 receptor antagonist (IL-1ra) was administered to 16 anesthetized, mechanically ventilated piglets that received a continuous infusion of group B streptococci (GBS) (7.5 $\times 10^{7}$ colony-forming units $\left./ \mathrm{kg} / \mathrm{min}\right)$. Systemic (Psa), pulmonary artery (Ppa), and wedge (Pwp) pressures and cardiac output were measured pre-GBS and every 30 min during GBS infusion. After $15 \mathrm{~min}$ of bacterial infusion the control group received normal saline, whereas the treatment group received a bolus of IL-1ra $(40 \mathrm{mg} / \mathrm{kg})$ followed by a continuous infusion of IL-1 $1 \mathrm{ra}(60 \mu \mathrm{g} / \mathrm{kg} / \mathrm{min})$. In comparing IL-1ra-treated animals with controls from the 15-min GBS baseline to the succeeding septic study period (45-120 min), the following treatment effects were noted (120-min values shown): mean Psa remained elevated in treatment compared with control animals $(12.7 \pm 2.5$ versus $9 \pm 3.5 \mathrm{kPa} ; p<0.001)$ as did $\mathrm{CO}$ $(0.21 \pm 0.07$ versus $0.13 \pm 0.08 \mathrm{~L} / \mathrm{min} / \mathrm{kg} ; p<0.001)$. Pwp decreased in the treatment compared to the control group over the study period $(1 \pm 0.3$ versus $1.6 \pm 0.7 \mathrm{kPa} ; p<0.02)$. Mean
Ppa and mean Pra were not different between groups over time. Median length of survival was significantly longer $(p=0.04)$ in treated $(226 \mathrm{~min})$ compared with control animals (150 min). These data suggest that IL-1 plays an important role in GBS sepsis and septic shock, and that IL-1ra may in part ameliorate the cardiovascular alterations associated with GBS sepsis in the neonate. (Pediatr Res 38: 704-708, 1995)

CO, cardiac output

GBS, group B streptococci

IL-1ra, human recombinant IL-1 receptor antagonist

Ppa, pulmonary artery pressure

PVR, pulmonary vascular resistance

Pwp, pulmonary wedge pressure

Pra, right atrial pressure

SV, stroke volume

Psa, systemic arterial blood pressure

SVR, systemic vascular resistance

TNF- $\alpha$, tumor necrosis factor- $\alpha$
IL-1 is a cytokine thought to occupy a proximal position in the inflammatory cascade leading to tissue injury during sepsis $(1,2)$. After its release, IL-1 influences the metabolism of arachidonic acid and results in increased synthesis of leukotrienes, prostaglandins, and thromboxane $\mathrm{A}_{2}(2)$. In addition, IL-1 acts synergistically with other cytokines, such as TNF $\alpha$, to potentiate the inflammatory response (3).

Investigators have focused on the role of $\mathrm{IL}-1$ as a prominent mediator of septic shock (3-6) and, in fact, have demonstrated

Received March 22, 1994; accepted June 22, 1995.

Correspondence: Ronald N. Goldberg, M.D., University of Miami School of Medicine, Department of Pediatrics (R-131), Division of Neonatology, P.O. Box 016960, Miami, FL 33101.

Supported by the University of Miami Project: New Born Presented in part at the Society for Pediatric Research Baltimore, MD, May 1992. that systemic administration of IL- 1 to experimental animals resulted in arterial hypotension $(3,7)$. These experimental findings are consistent with clinical observations associating septic shock with elevation in IL-1 levels, specifically in patients with Gram-negative bacteremia $(8,9)$ and in humans receiving endotoxin (10). Furthermore, sepsis-induced arterial hypotension and mortality have been positively modified in Escherichia coli-infected adult animals by infusion of an IL1ra $(4,6)$.

Although most studies have evaluated Gram-negative sepsis, recent work reveals that Gram-positive bacteria may also induce in vitro synthesis and release of IL-1 $(11,12)$. The data of Sullivan et al. (13) showed an early, transient elevation of serum IL-1 levels in a group of children who were infected with Staphylococcus aureus, Staphylococcus epidermidis, and 
enterococci, and who eventually died (13). However, the role and hemodynamic consequences of IL-1 in Gram-positive sepsis in the neonatal animal is as yet undefined.

We hypothesized that if IL-1 is an important mediator of sepsis, its blockade in the piglet infected with group B $\beta$-hemolytic streptococci would in part ameliorate many of the deleterious hemodynamic consequences of sepsis and improve length of survival. To evaluate this, we used human recombinant IL-1 receptor antagonist and studied its effect when given after GBS sepsis had been initiated in the neonatal piglet.

\section{METHODS}

Sixteen Yorkshire piglets less than 2 wk old were anesthetized with sodium pentobarbital ( $30 \mathrm{mg} / \mathrm{kg}$, intraperitoneally) for the surgical procedure. Femoral arteries and veins were cannulated and used for measurement of Psa, infusion of maintenance fluid and bacteria, and blood sampling. The left external jugular vein was cannulated, and the catheter was advanced into the right atrium and used for infusion of IL-1ra (Synergen, Boulder, CO), measurement of Pra, and the injection of ice-cold saline for determination of $\mathrm{CO}$ via thermodilution. A 5 Fr Swan-Ganz thermodilution catheter was placed into the left external jugular vein and advanced under fluoroscopy into the left pulmonary artery to measure Ppa, Pwp, and CO. Heparinized normal saline $(10 \mathrm{U} / \mathrm{ml})$ was infused continuously through the pulmonary artery catheter. A 5\% dextrose solution was administered via a peripheral vein at a rate of 6 $\mathrm{mL} / \mathrm{kg} / \mathrm{h}$. Vascular pressures were measured with pressure transducers (model P23-1D; Gould Instruments, Cleveland, $\mathrm{OH}$ ) and recorded on a multichannel recorder (model 7 polygraph, Grass Instrument, Quincy, MA).

A tracheostomy was performed and a 4-5-mm endotracheal tube inserted. Animals were ventilated with room air using a time-cycled, pressure-limited, infant ventilator (Bournes BP 200, Riverside, CA). Acceptable arterial blood gases were obtained by setting peak inspiratory pressure at $11 \mathrm{~cm} \mathrm{H}_{2} \mathrm{O}$, positive end-expiratory pressure at $2 \mathrm{~cm} \mathrm{H}_{2} \mathrm{O}$, and the respiratory rate at 35 breaths/min. Ventilator settings were not altered during the study period. Animals were paralyzed with pancuronium bromide using an initial dose of $0.2 \mathrm{mg} / \mathrm{kg}$, i.v., followed by an infusion of $0.4 \mathrm{mg} / \mathrm{kg} / \mathrm{h}$. Chloral hydrate $(100$ $\mathrm{mg} / \mathrm{kg}$ ) was given via a nasogastric tube shortly after the surgery was completed to sedate the animals through the study period. Rectal temperature was continuously monitored with a thermistor probe (Yellow Springs Instrument Co., Yellow Springs, $\mathrm{OH}$ ), and skin temperature was maintained at $38.5^{\circ} \mathrm{C}$ using a servo-controlled radiant warmer.

Group B $\beta$-hemolytic streptococci (type Ia/c isolated from an infected neonate cared for in the Neonatal Intensive Care Unit at Jackson Memorial Hospital) were cultured in ToddHewitt broth for $18 \mathrm{~h}$ at $37^{\circ} \mathrm{C}$. The bacteria were collected by centrifugation, washed twice in pyrogen-free saline, and resuspended in a sterile Ringer's lactate solution with 5\% dextrose. Bacterial concentration was determined by optical density $(420$ $\mathrm{nm}$ ) measurements to be $8.75 \times 10^{8}$ colony-forming units $/ \mathrm{ml}$. Sepsis was induced by infusion of bacteria at a rate of $7.5 \times$
$10^{7}$ colony-forming units $/ \mathrm{kg} / \mathrm{min}$. The infusion was continued until the animal died or $4 \mathrm{~h}$ had elapsed.

Dose response studies were performed using newborn piglets who received a continuous infusion of GBS as described above. We tested doses of IL-1ra ranging from 10 to $40 \mathrm{mg} / \mathrm{kg}$, which based on previous studies $(4,6,14)$ would assure the serum ratio of IL-1 to IL-1ra necessary to achieve a physiologic response. The dose used in this study was based on a dosage regimen that resulted in the most stable mean Psa during the infusion of bacteria.

Animals were randomly assigned to a treatment group ( $n=$ 8; $\bar{X} \pm$ SD; weight, $2756 \pm 657 \mathrm{~g}$; age, $9 \pm 3$ d) which received IL-1ra throughout the study or a control group $(n=8$; weight, $2916 \pm 529 \mathrm{~g}$; age, $9 \pm 2$ d) which received an infusion of normal saline. Fluids in the control group were adjusted so as to balance the total fluids received in the treatment group. After a 30-min stabilization period, hemodynamic (Ppa, Psa, CO, Pra, Pwp) and arterial blood gas measurements were obtained before any intervention (baseline). A continuous infusion of GBS was then begun. Fifteen minutes after the initial rise in Ppa (15-17) (secondary to the GBS infusion), all measurements and arterial blood gas determinations were repeated. Human recombinant IL-1ra was given as an i.v. bolus of $40 \mathrm{mg} / \mathrm{kg}$ via an external jugular vein over 5 min, beginning $15 \mathrm{~min}$ after the onset of pulmonary hypertension. After completion of the bolus, a constant infusion of IL-1ra was begun at a rate of $60 \mu \mathrm{g} / \mathrm{kg} / \mathrm{min}$. Measurements were subsequently repeated at 30 and $60 \mathrm{~min}$, and every $30 \mathrm{~min}$ in both groups until the animals died or $240 \mathrm{~min}$ from the onset of pulmonary hypertension had elapsed. Stroke volume, SVR, and PVR were calculated.

Handling and care of the animals were in accordance with the guidelines of the National Institutes of Health, and this study protocol was approved by the Animal Care Committee of the University of Miami.

Analysis of covariance with repeated measures was utilized to assess the response to treatment from 15 min after initiation of pulmonary hypertension up to and including $120 \mathrm{~min}$ for both groups for all variables (Psa, Ppa, Pwp, SV, SVR, PVR, heart rate, $\mathrm{CO}, \mathrm{pH}, \mathrm{PaCO}_{2}, \mathrm{PaO}_{2}$, and base deficit) using the 15 -min (GBS baseline) value as the covariance correction. This analysis includes tests between groups without regard to time and time-treatment interaction. In all cases treatment group differences were significant; however, only time-treatment $p$ values were reported. Statistical analyses did not include values after 120 min due to mortality in the control group after this time. Hemodynamic and arterial blood gas data were compared between groups at baseline using two sample $t$ tests. The Mann-Whitney $U$ test was used to compare survival time between groups. All animals were followed until death or until $240 \mathrm{~min}$ had elapsed. Data are expressed as mean \pm SD.

\section{RESULTS}

Age and weight were not significantly different between treatment and control animals. In addition, hemodynamic and arterial blood gas measurements at baseline and just before infusion of either IL-1ra or saline were comparable between 
groups. Initially, mean Psa increased in both groups after the bacterial infusion was begun (Fig. 1). Mean Psa values remained stable in both groups during the initial $60 \mathrm{~min}$ of bacterial infusion, while over the subsequent 60 min, mean Psa in the control group fell steadily to a value of $9 \pm 3.5 \mathrm{kPa}$ at 120 min. In contrast, mean Psa in the IL-1ra treatment group remained essentially unchanged at $12.7 \pm 2.5 \mathrm{kPa}$. These differences were statistically significant over time (timetreatment interaction, $p<0.001$ ).

Cardiac output initially decreased with GBS infusion in both groups (Fig. 2). However, the IL-1ra treatment group maintained a more stable $\mathrm{CO}(0.21 \pm 0.07 \mathrm{~L} / \mathrm{min} / \mathrm{kg}$ at $120 \mathrm{~min})$ compared with the control group in which $\mathrm{CO}$ decreased steadily to $0.13 \pm 0.08 \mathrm{~L} / \mathrm{min} / \mathrm{kg}$ (time-treatment interaction, $p$ $<0.001$ ).

Stroke volume fell in both groups (Fig. 2). The IL-1ra treatment group maintained a stroke volume ranging from 1.94 \pm 0.68 to $1.82 \pm 0.65 \mathrm{~mL} / \mathrm{kg} / \mathrm{beat}$ over the $60-120-\mathrm{min}$ period, whereas values in the control group fell from $1.92 \pm$ 0.52 to $1.34 \pm 0.62 \mathrm{~mL} / \mathrm{kg} /$ beat (time-treatment interaction $p$ $<0.01)$. Heart rate was not statistically different between groups (Table 1).

Both groups displayed significant increases in PVR and Pwp with GBS infusion (Fig. 3). Comparison of values over the study period revealed that values in the treatment group were significantly lower than that of the treatment group for both parameters (time-treatment interaction, $p<0.04$ ).

There were no statistically significant differences between groups for SVR or mean Ppa (Table 1). In addition, values for arterial blood gases and acid-base status between groups were not statistically different over the study period. $\mathrm{pH}$ values at the 15 -min GBS baseline were $7.34 \pm 0.03$ and $7.43 \pm 0.06$ and at $120 \mathrm{~min} 7.08 \pm 0.09$ and $7.24 \pm 0.17$ in control and IL-1ra groups, respectively. $\mathrm{PaCO}_{2}$ values were $4.8 \pm 0.7$ and $4.4 \pm$ 0.5 , and $6.4 \pm 1.3$ and $5.7 \pm 0.9 \mathrm{kPa}$ at 15 and $120 \mathrm{~min}$ in control and treatment groups, respectively. $\mathrm{PaO}_{2}$ values were also not significantly different and were $7.7 \pm 2.1$ and $6.9 \pm$ $0.7 \mathrm{kPa}$ at $120 \mathrm{~min}$ in control and treated animals, respectively.

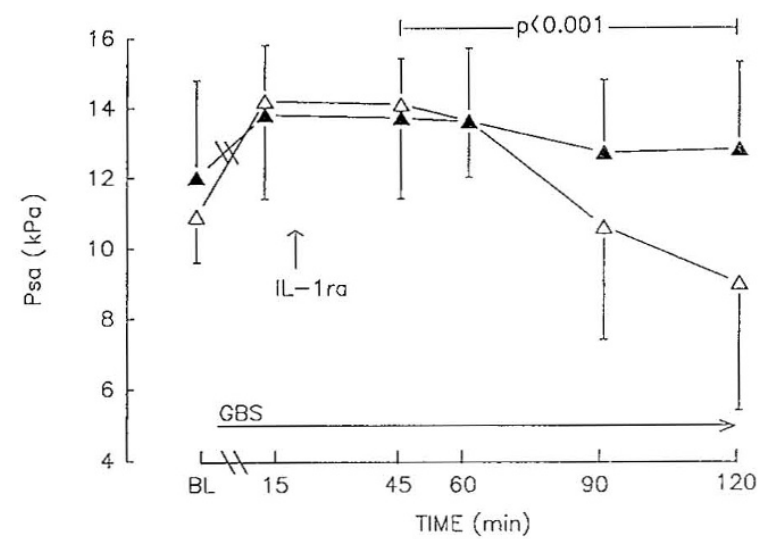

Figure 1. Arterial blood pressure changes in control $(\Delta)(n=8)$ and IL-1ra $(\boldsymbol{\Lambda})(n=8)$ animals receiving GBS infusion. IL-1ra animals displayed a significantly higher mean arterial blood pressure over time $(p<0.001)$. Values represent $\bar{X} \pm \mathrm{SD}$. The $p$ value represents time-treatment interaction by repeated measures analysis of covariance. $B L$, baseline.
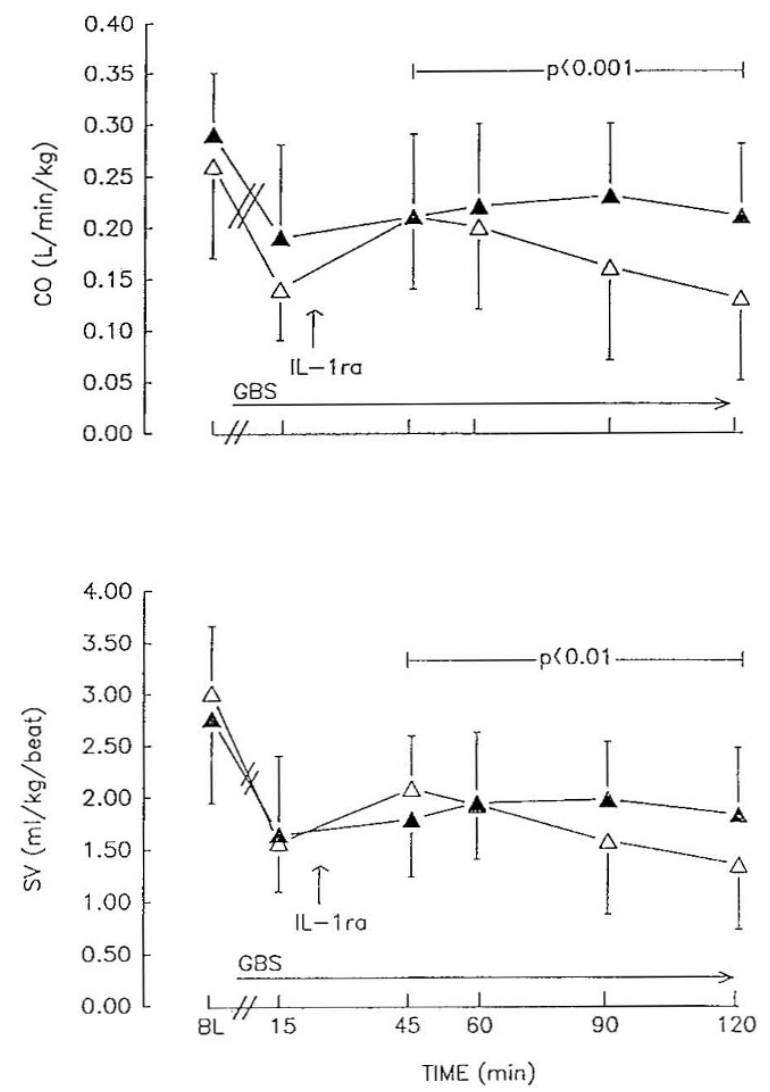

Figure 2. Control animals $(\Delta)(n=8)$ are compared to IL-1ra $(n=8)$ animals ( $\mathbf{\Lambda}$ ) with respect to cardiac output in the upper graph and stroke volume in the lower graph. IL-1ra animals display a significantly higher $\mathrm{CO}(p$ $<0.001)$ and SV $(p<0.01)$ over time. $B L$, baseline.

Median survival in the control group was 150 min (range, 120-191 min) and $226 \mathrm{~min}$ (range, 155-243 min) in the IL-1ra-treated group $(p=0.04)$.

\section{DISCUSSION}

The results of this study affirm previous findings implicating IL-1 as an important mediator of the myocardial dysfunction and hypotension accompanying bacterial sepsis $(3,7)$. In this study, animals treated with IL-1ra demonstrated a more stable mean Psa and $\mathrm{CO}$ when compared with control animals during bacterial infusion. Unfortunately, the study design did not allow definition of the mechanism explaining these findings; however, it is probable that the effect of IL-1 on the cardiovascular system is multifaceted, manifesting direct vascular as well as myocardial effects. Trinkle et al. (18), using a vascular smooth muscle preparation, demonstrated that IL-1 depressed smooth muscle contraction by decreasing the concentration of activator calcium required for myosin light chain kinase phosphorylation. In addition, they described alteration in smooth muscle actin expression in those muscle preparations exposed to IL-1. Beasley (19) provided evidence that IL-1 induced elevations in c-GMP which may result in decreased concentration of activator calcium. Furthermore, Finkle et al. (20) have recently suggested that cytokines may have a direct negative inotropic effect mediated through myocardial nitric oxide synthase. It is possible that, in our experiment, blockade 
Table 1. Hemodynamic variables

\begin{tabular}{|c|c|c|c|c|c|c|c|}
\hline & \multirow[b]{2}{*}{ Group } & \multicolumn{6}{|c|}{$\bar{X} \pm \mathrm{SD}$} \\
\hline & & Baseline & $15 \mathrm{~min}$ & $45 \mathrm{~min}$ & $60 \mathrm{~min}$ & $90 \mathrm{~min}$ & $120 \mathrm{~min}$ \\
\hline \multirow[t]{2}{*}{ HR (beats/min) } & Control & $239 \pm 36$ & $298 \pm 30$ & $283 \pm 40$ & $289 \pm 37$ & $281 \pm 40$ & $300 \pm 25$ \\
\hline & IL-1ra & $285 \pm 28$ & $300 \pm 20$ & $315 \pm 28$ & $313 \pm 44$ & $323 \pm 45$ & $330 \pm 32$ \\
\hline \multirow[t]{2}{*}{$\mathrm{Ppa}(\mathrm{kPa})$} & Control & $1.9 \pm 0.4$ & $5.5 \pm 1.2$ & $5.1 \pm 1.2$ & $4.9 \pm 1.1$ & $4.7 \pm 0.9$ & $4.7 \pm 0.9$ \\
\hline & IL-1ra & $1.7 \pm 0.3$ & $5.9 \pm 0.8$ & $5.3 \pm 0.5$ & $5.2 \pm 0.4$ & $4.7 \pm 1.1$ & $4.8 \pm 0.7$ \\
\hline \multirow[t]{2}{*}{ Pra $(\mathrm{kPa})$} & Control & $0.33 \pm 0.13$ & $0.40 \pm 0.30$ & $0.5 \pm 0.40$ & $0.40 \pm 0.30$ & $0.40 \pm 0.30$ & $0.30 \pm 0.13$ \\
\hline & IL-1ra & $0.30 \pm 0.13$ & $0.40 \pm 0.13$ & $0.5 \pm 0.13$ & $0.40 \pm 0.30$ & $0.40 \pm 0.13$ & $0.40 \pm 0.30$ \\
\hline \multirow[t]{2}{*}{$\operatorname{SVR}(\mathrm{kPa} / \mathrm{L} / \mathrm{kg} / \mathrm{min})$} & Control & $56 \pm 31$ & $94 \pm 28$ & $70 \pm 21$ & $73 \pm 24$ & $78 \pm 33$ & $87 \pm 55$ \\
\hline & IL-1ra & $44 \pm 18$ & $92 \pm 49$ & $76 \pm 40$ & $68 \pm 34$ & $64 \pm 30$ & $68 \pm 34$ \\
\hline
\end{tabular}
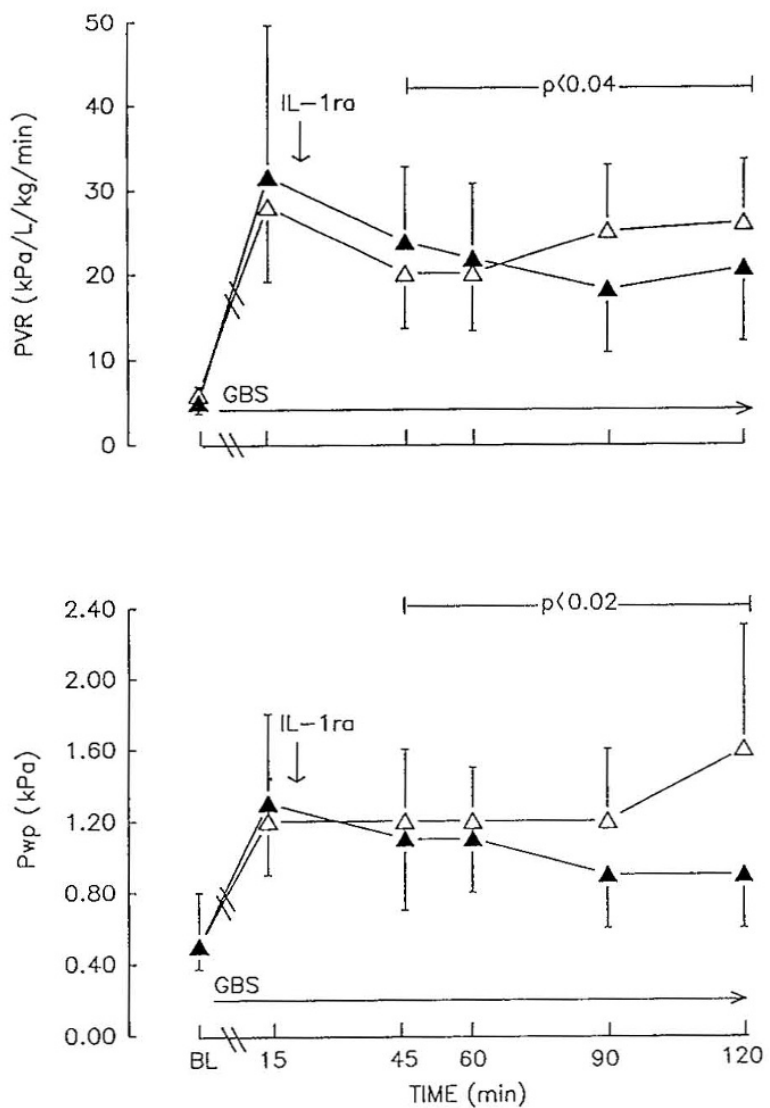

Figure 3. Control animals $(\Delta)(n=8)$ are compared to IL-1ra $(n=8)$ animals ( $\mathbf{\Lambda}$ ) with respect to PVR represented in the upper and Pwp in the lower graph. IL-1ra animals display a significantly lower PVR $(p<0.04)$ and Pwp compared to control animals $(p<0.02)$ over time. $B L$, baseline.

of IL-1 receptor sites by IL-1ra served to protect these myocytes from the deleterious direct effects of IL-1 and hence directly improved myocardial function.

Interleukin- 1 also interferes with the coupling of $\beta$-agonistoccupied receptors with adenylate cyclase, thus altering cardiomyocyte contractility. These data suggest that IL-1 may modulate the hormonal responsiveness and function of the cardiomyocyte (21). In our study, CO and SV, but not SVR or heart rate, were significantly different between the treatment and control groups, implying that the major differences between the groups may be due to differences in cardiac function, not vascular tone. We were not able to demonstrate a direct IL-1 effect because ventricular ejection fraction was not mea- sured. Therefore, although in vitro evidence of direct IL-1 activity on the myocardium exists (21), it is also possible that the improved cardiac output observed in the treatment animals was secondary to decreased right ventricular afterload as suggested by the significant fall in PVR.

The improvement in mortality in this study, as in others (6, 22), was most likely due to improved hemodynamic function as well as modulation of the inflammatory response secondary to a decrease in cytokine production. IL-1, -6, and -8 (23-26), as well as TNF- $\alpha$, are also reduced during IL-1ra administration (27), findings that may also account for the improvement in cardiac output and blood pressure in this model. As measurement of these cytokines was beyond the scope of this study, we cannot therefore assume that the improvement in survival and hemodynamic functions were solely related to IL-1 blockade.

Human recombinant IL-1ra was used in this study because the interspecies homology of IL-1ra is high. Compared with human IL-1ra, for example, murine IL-1ra is 75-77\% identical (28). We assumed that human recombinant IL-1ra would be effective in our septic piglet model as it has been used successfully in studies utilizing a variety of mammalian models (4, $6,29,30)$.

The IL-1ra dose chosen in the present investigation is high when compared with other reports. Wakabayashi et al. (4) used a pre-bacteremia bolus dose of $10 \mathrm{mg} / \mathrm{kg}$ of IL-1ra followed by a constant infusion of $15 \mu \mathrm{g} / \mathrm{kg} / \mathrm{min}$ to achieve a significant biologic response. In contrast, we were unable to demonstrate a significant response at these dosages during our preliminary dose-response studies. This may reflect an interspecies difference in response to IL-1ra infusion, the dose and type of bacteria used or, more likely, the fact that the present work tested IL-1ra in a treatment, as opposed to pretreatment model. IL-1 transcription occurs within $15 \mathrm{~min}$ in stimulated cells (31), whereas in in vivo studies translation and synthesis result in peak serum levels within $2-3 \mathrm{~h}$ post-bacterial challenge (32, 33). It is possible that during IL-1ra pretreatment many IL-1 receptor sites are occupied before bacterial stimulation of IL-1 transcription. This could conceivably result in a relative downregulation of the positive feedback effect that IL-1 typically produces after its synthesis by stimulation of transcription and translation, resulting in additional IL-1 (34). In the present study, it is possible that higher doses of IL-1ra were required in order to overcome the effect of an already ongoing, unchecked positive feedback loop. 
In summary, these data suggest that IL-1 plays an important role in mediating the hemodynamic manifestations of GBS sepsis. Specifically, treatment with IL-1 receptor antagonist ameliorates the decrease in cardiac output and mean arterial pressure as well as increases the length of survival in an acute, highly lethal model of neonatal GBS sepsis and septic shock.

Acknowledgments. The authors thank Cristina Varga for her excellent word processing assistance and Dr. Marylu Goldberg for her thoughtful review of this manuscript.

\section{REFERENCES}

1. Dinarello CA, Wolff SM 1993 The role of interleukin-1 in disease. N Eng J Med 328:106-13

2. Petrak RA, Balk RA, Bone RC 1989 Prostaglandins, cyclo-oxygenase inhibitors, and thromboxane synthetase inhibitors in the pathogenesis of multiple systems organ failure. Crit Care Clin 5:303-314

3. Okusawa S, Gelfand JA, Ikejima T, Connolly RJ, Dinarello CA 1988 Interleukin-1 induces a shock-like state in rabbits. Synergism with tumor necrosis factor and the effect of cyclooxygenase inhibition. J Clin Invest 81:1162 1172

4. Wakabayashi G, Gelfand JA, Burke JF, Thompson RC, Dinarello CA 1991 A specific receptor antagonist for interleukin-1 prevents Escherichia coli-induced shock in rabbits. FASEB J 5:338-343

5. Fong Y, Tracey KJ, Moldawer LL, Hesse DG, Manogue KB, Kenney JS, Lee AT, Kuo GC, Allison AC, Lowry SF, Cerami A 1989 Antibodies to cachectin/tumor necrosis factor reduce interleukin $1 \beta$ and interleukin 6 appearance during lethal bacteremia. J Exp Med 170:1627-1633

6. Ohlsson K, Bjork P, Bergenfelt M, Hageman R, Thompson RC 1990 Interleukin-1 receptor antagonist reduces mortality from endotoxin shock. Nature 348:550-552

7. Weinberg JR, Wright DJ, Guz A 1988 Interleukin-1 and tumor necrosis factor cause hypotension in the conscious rabbit. Clin Sci 75:251-255

8. Waage A, Brandtzaeg P, Halstensen A, Kierulf P, Esperik T 1989 The complex pattern of cytokines in serum from patients with meningococcal septic shock. Association between interleukin 6, interleukin 1, and fatal outcome. J Exp Med 169:333-338

9. Girardin E, Grau GE, Dayer JM, Roux-Lombard P, Lambert P 1988 Tumor necrosis factor and IL-1 in the serum of children with severe infectious purpura. N Eng J Med 319:397-400

10. Cannon JG, Tompkins RG, Gelfand JA, Michie HR, Stanford GC, van der Meer JWM, Enders S, Lonnemann G, Corsetti J, Chernow B, Wilmore DW, Wolff SW, Dinarello CA 1990 Circulating interleukin-1 and tumor necrosis factor in septic shock and experimental endotoxin fever. J Infect Dis 161:79-84

11. Reisenfeld-Orn I, Wolpe S, Garcia-Bustos JF, Hoffman MK, Tuomanen E 1989 Production of interleukin-1 but not tumor necrosis factor by human monocytes stimulated with pneumococcal cell surface components. Infect Immun 57:1890-1893

12. Hackett SP, Stevens DC 1992 Streptococcal toxic shock syndrome: synthesis of tumor necrosis factor and interleukin- 1 by monocytes stimulated with pyrogenic exotoxin A and streptolysin O. J Infect Dis 165:879-885

13. Sullivan JS, Kilpatrick L, Costarino JR, Lee SC, Harris MC 1992 Correlation of plasma cytokine elevation and mortality rate in children with sepsis. J Pediatr 120:510-515

14. Arend W, Welgus H, Thompson R, Eisenberg S 1990 Biological properties of recombinant human monocyte-derived interleukin-1 receptor antagonist. J Clin Invest 85:1694-1697
15. Runkle B, Goldberg RN, Streiteld MM, Clark MR, Buron E, Setzer ES, Bancalari E 1984 Cardiovascular changes in group B streptococcal sepsis in the piglet: response to indomethacin and the relationship to prostacyclin and thromboxane $A_{2}$. Pediatr Res 18:874

16. Sorenson GK, Redding GJ, Truog WE 1985 Mechanisms of pulmonary gas exchange abnormalities during experimental group B streptococcal infusion. Pediatr Res 19:922-926

17. Meadow W, Meus P 1981 An animal model of neonatal sepsis: early hemodynamic and metabolic sequelae of group B beta strep septic piglet. Pediatr Res 15:672A

18. Trinkle L, Beasley D, Moreland R 1992 Interleukin-1 $\beta$ alters actin expression and inhibits contraction of rat thoracic aorta. Am J Physiol 262:C828-C833

19. Beasley D 1990 Interleukin-1 and endotoxin activate soluble guanylate cyclase in vascular smooth muscle. Am J Physiol 259:R38-R44

20. Finkel MS, Oddis CV, Jacob TD, Watkins, Hattler BG, Simmons RL 1992 Negative inotropic effects of cytokines on the heart mediated by nitric oxide. Science 257:387389

21. Gulick T, Chung M, Pieper SJ, Lange LG, Schreiner GF 1989 Interleukin 1 and tumor necrosis factor inhibit cardiac myocyte $\beta$-adrenergic responsiveness. Proc Natl Acad Sci USA 86:6753--6757

22. Mancilla J, Garcia P, Dinarello, CA 1993 The interleukin-1 receptor antagonist can either reduce or enhance the lethality of Klebsiella pneumoniae sepsis in newborn rats. Infect Immun 61:926-932

23. Fisher E, Marano MA, Barber A, Lee K, Roch C, Hawes AS, Thompson RC, Hayes TV, Anderson TD, Benjamine WR, Lowry SF, Moldawer LL 1991 Comparison between the effects of interleukin- $1 \alpha$ and sublethal endotoxemia in primates. Am J Physiol 261:R442-R452

24. Granowitz EV, Clark BD, Vannier E, Callahan MV, Dinarello CA 1992 Effect of interleukin-1 blockade on cytokine synthesis. I. IL-1 receptor antagonist inhibits IL-1 induced cytokine synthesis and blocks binding of IL-1 to its type II receptor on human monocytes. Blood 79:2356-2363

25. Granowitz EV, Vanniere, Pontsiaka DD, Dinarello CA 1992 Effect of interleukin-1 (IL-1) receptor blockade on cytokine synthesis II. IL-1 receptor antagonism inhibits lipopolysaccharide-induced cytokine synthesis by human monocytes. Blood 79:2364-2369

26. Porat R, Pontsiaka DD, Miller LC, Granowitz EV, Dinarello CA 1992 Interleukin-1 (IL-1) receptor blockade reduces endotoxin and Borrelia burgdorferi stimulated IL-8 synthesis in human mononuclear cells. FASEB J 6:2482-2486

27. Aiura K, Gelfand JA, Burke JF, Thompson RC, Dinarello CA 1993 Interleukin-1 (IL-1) receptor antagonist prevents Staphylococcus epidermidis-induced hypotension and reduces circulatory levels of tumor necrosis factor and IL-beta in rabbits. Infect Immun 61:3342-3350

28. Eisenberg S, Brewer M, Verderber E, Heimdal P, Brandhuber B, Thompson R. 1991 IL-1 receptor antagonist (IL-1ra) is a member of the IL-1 gene family. Evolution of a cytokine control mechanism. Proc Natl Acad Sci USA 88:5232-5236

29. Boyce B, Yates A, Mundy G 1989 Bolus injections of recombinant interleukin-1 cause transient hypocalcemia in normal mice. Endocrinology 125:2780-2783

30. Eichacker P, Hoffman W, Farese A, Banks S, Kuo G, MacVittie T, Natanson C 1991 TNF but not IL-1 in dogs causes lethal lung injury and multiple organ dysfunction similar to human sepsis. J Appl Physiol 71:1979-1989

31. Fenton MJ, Clark BD, Collins KL, Webb AC, Rich A, Auron PE 1987 Transcriptiona regulation of the human prointerleukin 1 beta gene. J Immunol 138:3972-3974

32. Hesse DG, Tracey KJ, Fong Y, Manogue K, Palladino MA Jr., Cerami A, Shires GT, Lowry SF 1988 Cytokine appearance in human endotoxemia and primate bacteremia. Surg Gynecol Obstet 166:147-153

33. Clark BD, Bedrosian I, Schindler R, Cominelli F, Cannon JG, Shaw A, Dinarello C 1991 Detection of interleukin $-1 \alpha$ and $1 \beta$ in rabbit tissues during endotoxemia using sensitive radioimmunoassays. J Appl Physiol 71:2412-2418

34. Dinarello C 1989 Interleukin-1 and its biologically related cytokines. Adv Immuno 44:153-204 